\title{
Polite Discourse on the EARls' JOURNEY TO ROME: EXPLORING THE LEXICAL FIELD AND SENSIBILITY OF 'CONVERSATION' IN IRISH
}

\author{
LIAM MAC MATHÚNA
}

\section{Introduction and background}

Structured personal accounts of contemporary events and happenings composed in the Irish language are exceedingly rare in the pre-Revival period; that is to say, in the period prior to the founding of the Gaelic League or Conradh na Gaeilge in Dublin in 1893. The first such composition and the main focus of this paper is the account of the Ulster Earls' journey from Rathmullan in Co. Donegal to Rome in 1607-8. It was written by Tadhg Ó Cianáin, a member of the native learned class, who accompanied the Earls on their journey. The work is thought to have been penned in Rome in 1609-10, based on notes written along the way by Tadhg. It survives in a single manuscript copy, Tadhg Ó Cianáin's own autograph. The manuscript passed from Rome to the Irish College in Louvain in the mid-seventeenth century, was returned to Rome at the end of the eighteenth century, and was brought to Dublin in 1872. It is now in University College Dublin. The work was first printed in the twentieth century, the initial comprehensive edition being that of Fr Paul Walsh (1916). ${ }^{1}$ One of the many arresting features of Tadhg Ó Cianáin's participant account of the journey by the Earls is the significance accorded polite conversation in the Irish group's interaction with their aristocratic hosts along the way. Summary phrases such as Bātor sealat ag briatharchomrädh re aroile 'They spent some time in conversation with one another' and Bátor sealat ag imagallamh 7 ag äiness briathor re aroile 'They remained speaking and conversing with one another for some time' recur, as will be explored in this close textual analysis of meta-references to discourse.

Yielding to the pressures of the post-1603 peace agreement which had ended nine years of war against English forces in Ulster, the Earls felt that their position at home had become untenable, and they set sail for La Coruña in northern Spain on 14 September 1607 in the hope of gaining

\footnotetext{
${ }^{1}$ A more recent edition is that of Ó Muraíle (2007), which normalises the inconsistent orthography of the original text according to the standard of Classical Modern Irish. Much research on this text has been published in recent years: see, for example, Ó Muraíle (2013), Mac Craith (2011) and other essays in the two collections in which these appear.
} 
military support from the Spanish monarchy. However, their ship was blown off course in violent storms and they eventually landed in Normandy on 4 October, when they were down to their last five gallons of beer and final barrel of water. While the plight of the Earls generated much expression of sympathy on the Continent, they were essentially a political embarrassment and indeed a potential threat to the peace then prevailing between the great powers of western Europe. Accordingly, the Earls and their party were hurried on from France to the Low Countries. Refused passage to Spain by the Archduke, they eventually made their way to Rome, arriving there in May 1608.

Ninety-nine people had boarded the ship originally at Rathmullan, Co. Donegal, while approximately thirty travelled together in the Earls' party on their journey from Louvain to Rome in the spring of 1608. In Ó Cianáin's account of the vicissitudes of the Irish leaders and their followers, he is at constant pains to show how highly regarded the Earls and their entourage were by the governing Catholic classes of mainland Europe. The following are, inter alia, indications of the high esteem in which they were held for having fought against Elizabeth I on behalf of Catholicism in the nine years war, 1594-1603:

- they were met at the door of their palace by the Archduke and his wife;

- they were granted permission to enter churches and view relics;

- alongside the Spanish nation, the Irish nation alone were granted special permission to view town walls and defensive fortifications;

- they were invited to walk in procession behind the Pope in Rome, carrying the Eucharist;

- in particular, they were invited to meals, and accorded places of honour at dinners hosted by the Archduke, duke of Lorraine, governors etc.

But the particular concern of this paper is with conversation. I would like to begin by citing an example from Ó Cianáin of what might be described as every-day conversation, an occasion when information needed to be exchanged. ${ }^{2}$ Due to their straitened circumstances, as they countered adversity as best they could on the high seas, the Irish company felt it was prudent to make contact with those on board a number of large passing ships:

\footnotetext{
${ }^{2}$ In this article, meta-textual references relating to speech and conversation are highlighted in bold font.
} 
Timchiol mheadhōin laei dia māirt adchīd trī longa adhbalmōra ag ascnamh ōn aird uo dhess mar do thicfaitis ōn Spāinn. Ge gur imeglaigset in loinges sin gur mesatar gur d'armāil rīg Saxan ar ttoigheacht 'n-a niermhoirecht iad, brethnaigit aca fêin gur uo ferr döip dēnomh orra do chor a gconāich a gconntabairt, mad nāimde iad, nō madh catoilce, d'ierroidh scēl agus ēoluis orra, inās bheith san guasacht dermhair a mbātor a ttaep se[ac] hrāin agus aineōluis agus teirce dighe. Riccit fêin agus in loinges ar comhghar a chēile deōigh laoi. Eirgis ainfine adpol in tan sin as nach rāngator fëin 7 in loinges go cenn aimsire toigeacht a gcōir chomhráidh re aroile. As a haithle tra laprait re lucht na loingsi. Ierroit scēla orra. Innissit gur do chríchoibh Lochlann a mbunadhus, go rapsat ag tērnōdh tar aiss ōn Spāinn go a n-atharrdha badēin. Adbertsat gur sa ffairrge fFleminnaig bätar-san d'äirigthe.

About midday on Tuesday they saw three very large ships approaching from the south as if coming from Spain. Although they feared that squadron, and though they thought they belonged to the King of England's armament and were in pursuit of them, they considered that it was better for themselves to make for them and imperil their success if they were enemies, or, if they were Catholics, make inquiries and seek direction, than to be in the great danger in which they were in regard to going astray and mistaking the direction and scarcity of drink. They and the squadron came near one another at the end of day. A terrible storm arose at that time so that they and the squadron could not for a time come within speaking distance of one another. Afterwards, however, they spoke with the crews of the ships. They made enquiries of them. They told them that they were natives of Lochlainn, and that they were returning from Spain to their own country. They said that it was in the Flemish sea in particular they were.

(Walsh 1916: 10-3)

However, what is particularly striking in this work is the relatively high number of non-utilitarian, stylised references to the practice of conversation, most frequently at meals and banquets, but in other contexts as well. On closer examination, it seems that Tadhg Ó Cianáin's text testifies to the art of polite conversation being cultivated by Continental leaders at the time, in a milieu which otherwise might well have been a rough-and-tumble man's world of semi-demobilised officer-class soldiery. As visitors, the Earls were transient participants in this practice.

At any rate, the Earls' circumstances changed very much for the better as soon as they crossed the border from France into Flanders at the start of their Continental travels on 18 October 1607. It is clear from Tadhg's account that they were greeted warmly on their arrival in the first town, Arras. While no explicit reference to conversation is made at this point, the Irish were invited to a fine banquet, where wine flowed: 
An guibernōir bū̄ ó rīgh na Spāinne sa mbaili, glacuiss fềin 7 maithe na cathrach na tigernaidhe si chuca go subhailceach onōrach. Ticit ar cuairt dia saigidh go mbangcēd maith agus go ffintoibh. Cuirit athair onōrach maille re cōistigip taitnemhacha dia ttreōrugadh gusna prīmh-eguilsib oirrderca bātar sa gcathraigh. Taispentar ilimat do religiassoibh ronaomhtha mōr-lōigigheachta dōibh ar a mbū rann-chuid mhōr don chroich chēsta, cenn S. San Sem, cuid d'folt Muire Madalèn, cupa as ar ibh in Slānaigtheōir fēin deoch in tan buī a gcolainn daonna ar in saogal, go n-imat dī-äirmhe oile.

The governor himself, whom the King of Spain had appointed in the town, and the chief men of the city received these lords with kindliness and respect. They came to visit them, and held a splendid banquet with wines. They sent a reverend father with beautiful coaches to direct them to the famous churches which were in the city. Many holy precious relics were shown to them, including a large portion of the Cross of the Crucifixion, the head of St. James, a portion of the hair of Mary Magdalen, a cup out of which the Saviour Himself took a drink when He was in human flesh in the world, and numerous other things.

(Walsh 1916, 32-3)

If there were a term such as 'relic-vulture', to characterise a subset of the modern-day 'culture-vulture' tourists, we would have to apply it to our author, Tadhg Ó Cianáin, who displays an insatiable interest in saints' relics. The counter-Reformation Catholic ideology which was then in the ascendant among adherents of the old religion on the Continent was vigorously championing indulgences, relics and the cult of saints in the early seventeenth century, and as this quotation and many others testify, Tadhg Ó Cianáin was an enthusiastic devotee of these practices.

With respect to conversation, there were of course public occasions at which the emphasis was on formal speeches rather than the private exchanges which complemented them, as for instance when the party visited Douai:

Toirlingit ag colāiste Eirennach buī ar costus rīgh na Spāinne sa mbaile. Doghnít fèn oirissemh sa gcolāiste. ... Beiriss orra as Flonndrus an t-athair onōrach Flaithrī $O$ Maelconaire, pruincial uird minūir $S$. Proinsēiss a nEirinn ${ }_{7}$ in doctüir Roibert Mac Artuir. Rissin rēe aimsire so gabsat ag siobal ar cholāistibh na cathrach. Glacait coimhthionóil na gcolāistidhe chuca go ro-onōrach subhailcech íad mailli re uersaidhip 7 orāidip laitne grēgissi ${ }_{7}$ bērla do dēnam dōip. Ro chomhairimh aon don chuideachta a gcolāiste na iesuuit begān d'uiresbaidh ar dā chētt dég a n-èncholāiste amhāin. 
They alighted at the Irish College which was supported by the King of Spain in the town. They themselves stayed in the College, and they sent the better part of those with them through the city. They remained there until the following Friday. The reverend father, Father Ó Maolconaire, Irish Provincial of the Friars Minor, and Doctor Robert Mac Arthur met them here, having come from Flanders. During this time they went walking through the colleges of the city. Assemblies of the colleges received them kindly and with respect, delivering in their honour verses and speeches in Latin, Greek, and English. One of the company counted in the Jesuit College a little less than twelve hundred belonging to a single college.

(Walsh 1916: 36-7)

Interestingly, although Latin, Greek and English are mentioned explicitly here, there is no reference to Irish. One wonders whether Irish was already on the defensive, yielding public space to other, longer established tongues, in the case of Latin and Greek, and to English as a brash up-andcoming lingua franca for those hailing from Britain and Ireland. When the Earls went to visit the Infanta, the daughter of the king of Spain, and her husband Albert, the Archduke, who jointly ruled the Spanish Netherlands, both of them came to the door of the palace of their country residence near Binche to welcome the Irish travellers. From this visit on, we repeatedly encounter indications of the high social importance attached to conversation, as in the description of how the Infanta and the Archduke received the Earls:

Glacuit chuca go ro-onōrach airmitnech forffäilteach degh-aightheach maille re cūirtissighip mōra iad. Beirit lēo dia gcodal-tigh iad. Bátar sealat ag comrādh 7 ag coimhfhíerfaighe sgéul dieroile. Gabhait a gced. Eirgit fêin 7 diūc de Sana ${ }_{7}$ diúc de Oumal 7 mōrān do dhaoinibh uaissle oirrderca oile do dēnomh a medhōin laoi.

They received them with honour and respect, with welcome and kindliness, and showed them great courtesy. They brought them to their own private apartments. They spent a while in conversation and questioning one another. Afterwards they took their leave. They [the Irish] and the Duke of Ossuna, the Duke of Aumale, and many other illustrious noblemen went to dinner.

(Walsh 1916: 46-7)

Of course, the Irish were already renowned for their interest in news. One of the commonest of all Irish greetings continues to be Aon scéal agat? 'Any news?', paralleled by the phrase d'ierroidh scēl agus eōluis orra, already met with in the first passage quoted. Soon, the Earls and their entourage were in Brussels, visiting the Marquis and head of the army, 
General Spinola. Interestingly, two distinct occasions of conversation, or what one might term conversation/discourse acts, are recorded:

Ticc corenēl Francisco go līnmhairecht do chaiptīnip Späinneacha agus Eadāilleacha, Eirennacha ${ }_{7}$ Flonndrusacha, i n-a gcomdháil amach assin gcathraigh. Gluaissit uile tria shräidip oireghdha in baile go rāgatar dorass pālāiss in marcēiss. Tāinic in marcēiss fềin 7 nunsiuss in pāpa agus ambasadōir rīgh na Spāinni agus diūc de Suna dia nglacadh as a gcōistighip. Ier fforffäiltiugadh re aroile go līnmhar döip tiaghait assa haithle ar halla in marcēiss. Bātor sealat ag bríathar-chomrädh re aroile. Eirghit ' $n$-a dheaghaidh gusin tteghduis $i$ n-a ngnäthaigedh in marcēiss a chuid do chaitheamh. An marcēiss badēin ba hé ro shuidigh cāch. Cuiriss $O$ Nēill i n-a shuidhe i n-a ionadh fẽin a gcert-édan in büird, nunsius in pāpa dia lāimh dheiss, ierla Tíre Conaill dia lāimh chlü, clann Ū̃ Nēill agus Maguidir sīoss ōn ierla, ambasadōir rīgh na Spāinne 7 diūc de Umaar ar in taop oile sīoss ón nunsius. Coimhlín in büird do dhaoinip uaissle oirmhitnecha onōracha cenmothā sin, an marcēiss badēin 7 diūc de Suna ag fir-chionn in buird as comhair Ū̄ Nēill. Ba lōr a onōraighi 7 a rōchostusaighi ar bith, dia madh rī no-biadh ann, läin-fheabhus in medhōin laoi dorōnsat. Nìr uo messa-sa-chāch in bangcéd. Do taispenadh plāta ōir agus airgit astigh nār uo himnāir do rīgh nō prinnsa sa crīstaighecht do bheith aige. Bätor sealat ag conuersáit 7 ag áines bhriathar. Gabhait a gcet maille re buidhechus do thabairt dia chēile. Léigit tar aiss an oidhche sin go Noutre Dam iad.

Colonel Francisco, with many Spanish, Italian, Irish, and Flemish captains, came out of the city to meet them. They advanced through the principal streets of the town to the door of the Marquis's palace. The Marquis himself, the Papal Nuncio, the Spanish Ambassador, and the Duke of Ossuna came to take them from their coaches. When greetings had been exchanged in abundance, they entered the hall of the Marquis and spent some time in conversation. Afterwards they entered the apartment where the Marquis was accustomed to take food. He himself arranged each one in his place, seating Ó Neill in his own place at the head of the table, the Papal Nuncio to his right, the Earl of Tyrconnell to his left, Ó Néill's children and Maguidhir next the Earl, and the Spanish ambassador and the Duke of Aumale on the other side, below the Nuncio. The rest of the illustrious, respected nobles at table, the Marquis himself, and the Duke of Ossuna, were at the end of the table opposite Ó Néill. The excellent dinner which they partook of was grand and costly enough for a king, and nothing inferior was the banquet. Gold and silver plate was displayed inside that no king or prince in Christendom might be ashamed to have. They spent some time in conversation and chatting, and then took leave and returned thanks to one another. They retired that night to Notre Dame de Hal.

(Walsh 1916: 46-9) 
More polite discourse followed when the Irish arrived in Nancy, and were welcomed to the Duke of Lorraine's quarters:

Cuiriss tra in diūc cōistide ${ }_{7}$ daoine uaisle i $n$-a gcomhdhäil sealat ōn chüirt. Ier ttoirling dōip tic stībhard in diūc dia ttochuiredh gusin pálāss mōr. Gapait a leith-scēl do bïthin a n-aisstir an oidhche sin. Ier n-ëistecht aiffrinn ar n-a mhärach tic in fer cētna go gcōistigib maithi $i$ n-a gcomhairrchis. Eirgit ier sin don pālāss. Bätor ag sibal 7 ag spaisteōracht a ngalari ba lōr mētt 7 feabhus 7 deissi sa doman in comhfhat bū̄ in diūc issin eagluiss ag eistecht aiffrinn. Ticis in diūc ōn egluiss as a haithle. E fền a n-ēdach imchubhaidh. Drong dia dhaoinip uaisle ag comhrädh friss. A dhīss mac i n-a deghoidh. Gārda roi-dhess. Pāitside līnmara ar gach taop de. Ar ndol dā halla cuiriss tigernaidhi mōra i n-a gcoinne sen. Tēighit dia lāthoir. Glacuis chuicce go honōrach forffäilidh iat, a chlann mar an gcētna. Bātor sealat ag imagallamh 7 ag äines bhriathar re aroile. As a haithle suidit ar a medhōn laoi. Seiser dōib, an diūc co n-a dīss mac, $O$ Nèill, in t-iarla agus in barún. Imat do daoinib uaisle roonōracha ag feithemh orra. Beiris leis dia sheomra codalta i n-a deghaidh iad. Bātar ann sealat. Gabuit a gced. Eirgit dia löistīnibh. Ierla ba hardstīuartt don diūc i n-a gcoimhitecht. Fōgrais a pēin mōir gan ōr nō airget do glacadh uaidip in airett no-beittiss issin chathraigh, acht a n-uile chosstus frisin rē sin do beith ar in diūc.

The Duke sent coaches and noblemen a distance from the Court to meet them. When they alighted the Duke's steward called to invite them to the great palace, but they excused themselves for that night because of their journey. After they had heard Mass on the next day the same man came to meet them with good coaches. They then went to the palace. They remained walking and passing the time in an extensive, excellent, beautiful gallery while the Duke was in the church hearing Mass. He came from the church afterwards. He himself was in becoming dress, with some of his noblemen discoursing with him, and his two sons after him. He had a very beautiful guard, and many pages on either side of him. When he came to his hall he sent great lords for them [the Irish]. They went into his presence. He received them with joy and honour, and his children did likewise. They remained for a time discoursing and conversing with one another. Afterwards they sat down to dinner. They were six in number, the Duke and his two sons, Ó Néill, the Earl, and the Baron [of Dungannon]. There were many honourable noblemen waiting on them. He brought them afterwards to his private apartment. There they remained for a time. They then took their leave and retired to their lodgings. There was an Earl, who was head-steward of the Duke, accompanying them. He proclaimed under severe penalty, that no one should accept gold or silver of them while they should be in the city, but that all their expenses during that time should be borne by the Duke.

(Walsh 1916: 78-9) 
If there is an optimal number of participants which fosters conversation, there are strong indications that it may be six, as the following account from another journey, undertaken some three hundred years later demonstrates. This quotation comes from Dr Douglas Hyde's description of his fund-raising tour of the United States in 1905/06 as first President of the Gaelic League. In Irish, Hyde was known as Dúbhglas de h-Íde, or by his pen-name An Craoibhín Aoibhinn, often abbreviated to An Craoibhín. Hyde seems to have been extremely gregarious and sociable. His diary reports of his tour of the United States in 1905/06, Mo Thurus go hAmerice, when he criss-crossed the continent in order to raise funds for the Gaelic League, include frequent accounts of dinner parties which continued into the early hours, and conclude with statements such as shuidheamar os cionn ár bhfiona go dti leath-uair tar éis a haon, 'we sat over our wine until half past one' (An Craoibhín Aoibhinn 1937: 165) which occur again and again. However, there was one particular day-time occasion in New York, from which he derived exceptional satisfaction:

An Sémhadh Lá Fichead de Bhealtaine. Chuaigh mé chum lóin ag Tigh Delmonico le Mac Ui Chuinn, Mac Uí Chathaláin, Brisbane, an Breitheamh Mac Eóchaidh agus Peadar Fionnlaigh Ó Duinn .... Do shuidheamar chum lóin ar a haon a chlog agus nior fhágamar an áit go dtí a sé. A leithéid de chaint ní chuala mé ariamh, 'chuile dhuine againn ag caint agus ag sgéalaigheacht. D'éirigheadh Mac Uí Dhuinn gach ceathramhadh uaire le labhairt ar an ngothán le duine éigin 'á rádh go mbeadh sé ar ais i gceann ceathramhadh uaire eile, acht d'imthigh ceathramhadh uaire $i$ ndiaidh ceathramhadh uaire, agus nior chorruigh sé! Bhí mise 'mo shuidhe le n' ais agus bhí mórán cainte agam leis. Tá baint aige, saoilim, le Clann na nGaedheal... Nior bhfhorus é, saoilim, seisear fear eile do thabhairt le chéile cosamhail leis an seisear do bhí againn indiu, ag an lón so.

(An Craoibhín Aoibhinn 1937: 163-4)

26 May. I went to lunch in Delmonico's with Quinn, Cohalan, Brisbane, Judge Keogh, and Peter Finlay Dunne .... We sat down to lunch at one o'clock and we didn't leave the place until six. I never heard the like of the talk before, everyone of us speaking and telling stories. Dunne would get up every quarter of an hour to speak on the phone to someone saying he would be back in another quarter of an hour, but quarter of an hour after quarter of an hour passed, and he didn't move! I was sitting beside him and I spoke to him at length. He is connected, I think to Clan na Gael... It wouldn't be easy, I think, to bring six men together like the six of us today, at this lunch. ${ }^{3}$

\footnotetext{
${ }^{3}$ Translation by the author. A wide-ranging comparison of the accounts of Ó Cianáin and Hyde is to be found in Mac Mathúna (2015).
} 
When the Ulster chiefs journeyed as far as Parma in Northern Italy, the Duke of Parma himself came to meet the Irish party; he too is said to have engaged them in polite conversation and discourse for a while, sealat, before they parted:

Ier ttoirling dōip ag cathraigh Parma tig ierla onōrach don tīr d'forffāiltiughadh frīu agus dia nglacadh go honōrach a n-ainm diūc de Parma. Täinic ar n-a mhārach immorro go gcōistighip ro-mhaithe $i$ n-a gcomhdhāil dia ttreōrugadh gusin airm a mbū̄ in dī̄c. Gabuis tra in dī̄c chuicce go honōrach airmhitneach iatt. Bátor sealat ag imagallamh 7 ag äiness briathor re aroile. Gapait a gcead as a haithle. A n-imfhoixe gāirdīn in diūic taisselbthor dōip lipartt 7 dā leōman.

When they dismounted at the city of Parma a noble earl of the country came to welcome them and receive them in the name of the Duke of Parma. The next day he came with good coaches to them to conduct them to where the Duke was. He received them with honour and respect. They remained speaking and conversing with one another for some time. Then they took their leave. Near the Duke's garden they were shown a leopard and two lions.

(Walsh 1916: 102-4)

We may note with regard to áines(s), which we have now encountered several times in relation to discourse and conversation, that its primary meaning is 'splendour; pleasure; play, sport; bliss (of heaven)', and that it occurs in this sense in Tadhg's text, as, for instance, in the following account of ice breaking up when crowds were cavorting on the frozen river in Louvain:

An lucht ro buī ag fastaeim, ag äiness 7 ag aoipness roimhe sin, ní mōr nār uo toltanaighe leō beith astigh go comhnaigtheach a gcert-mhedhōn na cathrach ināss beith ar in seōltōracht sin, bïdh nach beittiss a n-aighthe ar in sen-fhairrgi ar a gcomhghar.

The crowd which had been sporting and playing and merrymaking before would almost have preferred to be at rest inside in the centre of the city than to be drifting thus, even though their eyes would not be on the sea, which was near to them.

(Walsh 1916: 58, 59)

Another example refers to the Duke of Parma's pleasure boats:

Dā beg-loing dessa go tteghduisip lonnradhacha ag diūc de Parma ar in ruibèr i n-a mbī fềin ag äines agus ag caithem aimsire sechnōin in ruibēir an tan ba toil leis. 
The Duke of Parma has two small pretty boats with white houses, in which he himself delights and amuses himself up and down the river whenever he wishes.

(Walsh 1916: 102, 103)

In this latter citation ag áines is linked with ag caithem aimsire and we may recall that when áines combines with briathar 'word' to form briathar-áines that sealat 'a while' is often used alongside it.

Tadhg recounts how, when they met the Pope himself on May $4^{\text {th }}$ 1608 , they had a one-hour audience with the Pontiff, but in this case the lexicon used is that of asking the Earls for an account of their experiences, sharing news - ag comfhierfaighi a scēl 7 a n-echtra frisin rē sin, 'asking them of what occurred to them and how they had fared', literally 'asking them [to recount] their news and their adventure up until that time': ${ }^{4}$

An cethramadh lā do mhī maíi domhnach araoi laithi sechtm[ain]e aoiss in Tigerna in tan sin mìle ar sē chèt ar ocht mbliadhnaibh ro thoiligh naomhthacht in pāpa dōip as go ragdaois $i$ n-a persanoibh badhdēin dá lāthair in tres uair ier medhōn láoi. Cuirit na cardenáil buidhen do chōistidhip ro-mhaithi go n-eachraidh ba lōr feabus ${ }_{7}$ deissi issin doman $i$ $n$-a gcomhairrchis dia gcoimht[h]reōrughadh gusin dū $i$ n-a mbaoi in pāpa. Eirgit gussan pālāss ro-onōrach dar comhainm Monte Caualle. In t-athair naomtha Paulus Quintus ar a gcinn annsin. Ar ndol dia lāthair dōip gabuis chuice go ro-onōrach grāssamail mōrānta forfāilidh iad. Ier sin doratsat badhdèin co n-a lucht coimhitecht[a] diaig a ndiaig pōic dia chois bennaight[h] e maille fri humhla 7 reuerens. Bätar tra timchell uaire do lō $i$ n-a lāthoir, é onōrach supāilcech degh-aigthech ag comfhierfaighi a scēl, a n-echtra frisin rē sin. Gabhait a gcet ier mbenedixion mbennaigthi d'fogbāil. Dobeirit altugadh do Dia 7 don athair naomtha fo bhïthin a onōraighi airmitnighi ro thaisspēin a s[h]upāilce mōr-thrōcairecha dhóip. As sin dōip go cardenāl Burgeis mac derpsethar in pāpa. Ba fäilidh rompa. Ier sin gussin pālāss $i$ n-a mbātar dīss derbrāthar in pāpa. Fāiltigit friū. Ro gapsat as a haithle go hambasadōir rīgh Frannc ro buī ag fāgbāil na cathrach ar n-a mārach do shonnradh. Comnaigit cusin díardaoin buī ar a gcinn. Bātar tra cardenáil na cathrach frissin rē sin ag cor mèitte äirigthi do dhaoinibh uaisle adhamra 7 d'oifficechaibh ro-onōracha d' forfäiltiughadh friú aguss dia nglacadh go hairmitneach as a n-ucht badhdéin.

On the fourth of May, the day of the week being Sunday, and the year of the Lord being then one thousand six hundred and eight, his Holiness the Pope consented to their coming in person into his presence at three o'clock in the afternoon. The cardinals sent a number of good coaches, and some

\footnotetext{
${ }^{4}$ For explication of the lexical field 'story' see Mac Mathúna (2004).
} 
of the most excellent and most beautiful horses in the world, to them, to conduct them to the place where the Pope was. They went to the splendid palace which is called Monte Cavallo. The holy Father, Paul V, was awaiting them there. When they appeared before him, he received them with respect, with kindness, with honour, and with welcome. Then they themselves and their followers, one after another, kissed with humility and reverence his holy foot. They were about one hour of the day in his presence, and he was courteous, glad, and kind to them during that time, asking them of what occurred to them and how they had fared. They took their leave after having received holy benediction. They gave thanks to God and the holy Father for the respect and the reverence wherewith he had exhibited his great, merciful kindness to them. From there they went to Cardinal Borghese, the son of the Pope's sister. He showed them welcome. After that they went to the palace where there were the Pope's two brothers. They also made them welcome. Then they went to the ambassador of the King of France, who was about to leave the city on the following day. They rested until the next Thursday. During that time the cardinals of the city continued to send a number of great noblemen and of very high officers to welcome them and to receive them with respect in their own behalf.

(Walsh 1916: 170-3)

Tadhg Ó Cianáin includes two lengthy, if somewhat digressive, accounts, in his diary travelogue, namely the history of the house of Loreto and the life of St Honophrius, who dwelt in the desert. When the infant Jesus met St Honophrius as a mere three-year-old, he addressed the Lord, using the formal, polite second person plural pronoun sipsi: a T[h]igerna, lenamh sipsi; meisi lenamh oile; 'O Lord, Thou art a child; I, too, am a child,' (Walsh 1916: 226, 229). We are told that the two played together, engaging in holy conversation: Bätor sealat ag lenbacht 7 ag diamairnaomthacht chomhräidh re aroile. 'They remained for a while playing and in holy converse with each other' (Walsh 1916: 226, 229).

\section{Táin Bó Froích}

Whether one moves backwards or forward in time from the period when the Earls were on the Continent, one will come across fine instances of sensibility centring on conversation and speech acts in the broad sweep of Irish literature Two such examples are to be met with in the late Old Irish tale, Táin Bó Froích, edited by Wolfgang Meid. Ailill and Medb are afraid that their daughter Findabair will elope with Froech and are discussing the matter in private when who should come by but Froech himself:

'Ad águr-sa,' ol Ailill, 'élud inna hingine ucut la Fróech.'

'Ce do berthae dó nibu madae,' ol Medb, 'ocus do 'téised ar ndochum 
cona chethrai do chobair dúinn ocin táin.'

Do'tét Fróech cuccu issa tech n-immacaldmae.

'In cocur fil lib?' ol Fróech.

'Dot'allfa-su and,' ol Ailill.

'In tibéraid dam-sa for n-ingin?' ol Fróech.

Imma'n-aiccet int slúaig.

'Do bérthar', ol Ailill, 'día tucae tindscrae amail as bérthar.'

'Rot'bia', ol Fróech.

(Meid 2015: 44, lines 136-45)

That is to say:

'I fear', said Ailill, 'the eloping of the girl there with Froech.'

'If she were given to him, it would not be in vain', said Medb, 'since he might come to join us with his cows to help us at the foray.'

Froech goes to them into the house of counsel.

'Is it a private conversation you are having?' asked Froech.

'There will be room for you in it', said Ailill.

'Will you give me your daughter?' asked Froech.

The hosts look at one another.

'She will be given', said Ailill, 'if you bring the bride-price as it will be named.'

'You shall have it', said Froech.

(Meid 2015: 68)

In fact, Ailill and Medb try to trick Froech by getting him to undertake the dangerous task of picking berries from the bank of the lake called Dublinn. However, this ploy had the unexpected outcome of allowing Findabair to behold Froech's body as he swam, and led her to utter this poetic reaction as a stock account she is said to have repeated throughout her life:

Ba hed iarum aithesc Findabrach, nach álaind ad'chíd, ba háildiu lee Fróech do acsin tar dublind, in corp do rogili ocus in folt do roáilli, ind agad do chumtachtai, int súil do roglassi, os é móethóclach cen locht cen anim, co n-agaid fochail forlethain, os é diriuch dianim, in chráeb cosna cáeraib derggaib eter in mbrágit ocus in n-agid ngil. Is ed as bered Findabair: 'Nicon acca ní ro sáised leth nó trian dia chruth'

(Meid 2015: 45, lines 181-6)

This was Findabair's response thereafter whenever she would see anything beautiful, that it was more beautiful to her to see Froech (swimming) across the blackpool - the body of extreme whiteness, the hair of extreme beauty, the face for shapeliness, the eyes of shining blue, and he a gentle youth without fault, without blemish, with face narrow below, broad above, and he straight and flawless, the branch with the red berries 
between the throat and the white face. This is what Findabair used to say: 'Never have I seen anything which would have reached half or one third of his beauty.'

(Meid 2015: 69-70)

\section{Caithréim Thoirdhealbhaigh}

Caithréim Thoirdhealbhaigh, a remarkable fourteenth-century tour de force saga of near-contemporary strife in Thomond, or what is now County Clare, includes quasi-mythological identification with the cosmic order. Recalling the asseverations of the sagas, ${ }^{5}$ Thomond warriors vow that they will not abandon their chief, Maccon, until the cosmic order itself is rent. Appeal is made first of all to land, water, sun and moon, and avoidance of earthquake, rather as in the pre-Christian tripartite reference system of land, sea and sky, with a slightly muddled Christian contrasting of Paradise (taking the place of Heaven) and Hell, in place of the more regular binary opposition of heaven and earth:

Is and sin atbert Maccon do guth glansholus gégdígaind: nomfágbaid ar firdeiredh a óga bar eisiun, agus nachamaincedh énfer agaibsi, agus coimédaidhsi dá taob agus tosach na tromcreiche co triathShinaind. agus dob é seo fregra na fedhnach sin ar a bflaithmilid: fad mairfid cairrgi ós caladhaib, agus srotha ar sirimtecht, agus grian a nglanrothaib, agus ésca ag imláidib, agus talam gan taobimpód, ní theichfemne; agus nó go tuca uasalparrthus imláid áirde d'uaim ifern ní fúigfemne thusa gan tuitim d'ár trénairechtaib ad timcheall.

(O’Grady 1929a: 74-5)

It was then that Maccon said with pure, bright, strong-sinewed voice: 'young men, leave me in the very rear, said he, and don't let any man of you come to aid me; but keep charge of both sides and the front of the great prey as far as the lordly Shannon.' And this was the answer of those troops for their princely soldier: 'so long as rocks shall stay above shores, and streams continually flow, the sun hold its radiant course, the moon wax and wane, and the earth not turn on its side, we will not flee; and until noble Paradise shall exchange height with Hell's cave we will not desert you, unless our strong companies fall around you. ${ }^{6}$

On the other hand, in this linguistically highly charged text we also find a pragmatic and virtually modern-day appreciation of the need for a leader

\footnotetext{
${ }^{5}$ See Mac Mathúna (2012b) for comprehensive analysis of the content and underlying values of this text, and Mac Mathúna (2014) for discussion of the conceptual and cultural nature of the cosmic world view of the Irish, as set out in the early literature.

${ }^{6}$ Translation by the author, taking cognisance of O'Grady's earlier translation (O'Grady 1929b: 67).
} 
to appeal to a wide variety of interests and power brokers, and the characteristics seen as desirable in a king are set out in list-like form. If the chieftains, poets, hospitallers and warriors were the types of groups who benefited from a successful king (or who, in other words, had to be satisfied by him), it is no wonder that their support, and that of others, had to be attained in advance. This is clear from an insightful passage in Caithréim Thoirdhealbhaigh, recording the qualities that various groups or constituencies valued in a leader: on the death of one leader, Donnchad, Clancullen hurriedly chose Lochlainn, whom no one opposed, as his successor. Lochlainn's talents were manifold and satisfied everybody:

do toghatar na tuatha ar a thoirbertaib in trénmilid, agus a chine ar a chonailbe; a laochrad ar a ghníméchtaibh, a bhrugada ar a bhognáraige, agus a fileda ar a fhialbuada; a amhais ar a innsaigtib, a chléirig ar a chertriaglaigtib, a óig ar a airbidnige agus a mhná ar a mhilisghlóraige; nár chinn táiseach ar testaib trénLochlainn $i$ réim ná $i$ rígteghdais.

(O’Grady 1929a: 45)

The tuatha chose the strong soldier for his accomplishments; his own kin, for his brotherly affection; his warriors, for his exploits in war; his hospitallers, for his good-natured deference; his poets, for his qualifications of liberality; his mercenaries, for his martial enterprise; his clergy, for his strict rule of life; his young men, for his honouring; and his women for the mellifluous nature of his speech. No chief exceeded strong Lochlainn's fame in the matter of government or in the maintaining of a great chief's household. ${ }^{7}$

\section{Eólas ar an Domhan}

Moving beyond Tadhg Ó Cianáin on the time-line to the 1720s we encounter a lively geography textbook composed in Dublin by another Tadhg, Tadhg Ó Neachtain, viz. Eólas ar an Domhan 'Knowledge of the World'. Although largely based on two English-language texts, namely, $A$ Most Compleat Compendium of Geography by Laurence Eachard (1691) and Geography Anatomized by Patrick Gordon (1699?), the whole is framed in the form of a dialogue between Tadhg and his father Seán, both school teachers. This device, whereby Tadhg enquires and Seán expounds, allows Tadhg to foreground, albeit in the rather unlikely context of a textbook, the expression of sensibility between father and son, and to give explicit expression to a level of affection which is otherwise largely wanting from Gaelic literature.

\footnotetext{
${ }^{7}$ Author's translation, drawing on O'Grady 1929b: 43.
} 
This geography textbook begins as follows, with a rather stiff questionand-answer sequence with reference to the continent of Europe (for which the Irish term rann is used by Ó Neachtain):

'Athair ionmhuin, a ndeir tū liom gurab mó don domhan talmhuidhe atā faoi ain-Chríostuighthibh nō fo Chrīostuighthibh? - Is mó, go deimhin, òir fad na hEurōipe, i. an rann Chrīostamhuil, 3420 míle Iotāileach (do réir mheasta), \& leithead 2220; 7 is ó Eurōp inghean Agenor, Righ Phaenicia goirthear Eurōip dī.

(Ní Chléirigh 1944: 1)

Dear father, do you say to me that there is more of the earth's land which is under non-Christians than under Christians? - It is greater, indeed, as the length of Europe, i.e. the Christian continent, is 3420 Italian miles (according to estimate), and the width is 2270; and it from Europe daughter of Agenor, king of Phoenicia that she is called Europe). ${ }^{8}$

The text continues in this vein, although for the most part, it reflects the formal question and answer format, which one associates with a religious catechism, rather than a relaxed conversation. There are, however, a few exceptions, the most striking of which is the following pleasing interlude, which comes more than halfway through the work, when Tadhg would like Seán to begin an exposition on Asia:

A Athair chátuidh, an codhladh dhuit?

Ní trom é.

Guidhim thú 7 taistiol an Asia riom, 7 nā fāg clúid oilén nó rōoghacht innte gan fhoillsiughadh.

Breaghadh é, a Thaidhg! Nach ndearnas craoibhsgaole ar chrīochuibh na hEuróipe dhuit cheana?

Do-rinnis go deimhin. Gidh éadh nī bhíad sásta (do réir t'eóluis) muna n-airisir ní éigin ar dháluibh an chuid so don chruinne.

Tà tù roidh-dhian oram, a mhic mo chroidhe.

Mun' ar cairid, ní ar namhuid.

Is fior soin, oir admhuighim nach bhfuil san domhan (d'éis bháis do mhāthar Úna Ní Bhruin) is ionnsa liom nā thú. Uime sin labhōrad beagān beag go hathchumair ar an rann soin.

(Ní Chléirigh 1944: 106-7)

O esteemed father, are you asleep?

Not deeply.

I pray you, and travel Asia with me, and do not leave any corner, island or kingdom in it undisclosed.

\footnotetext{
${ }^{8}$ Author's translation.
} 
That's fine, Tadhg! Haven't I expounded on the territories of Europe to you already?

You did, indeed. However, I won't be happy (as you know) unless you tell me something about the circumstances of this continent of the world.

You're too hard on me, son of my heart.

If it's not to a friend, it's not to an enemy.

That's true, because I have to admit that there is nobody in the world (after the death of your mother Úna Ní Bhroin) who is dearer to me than you.

Therefore, I will speak a little bit in summary of this continent. ${ }^{9}$

\section{Conclusion}

As we have seen, Tadhg Ó Cianáin's account of the Earls' journey to Rome includes many instances where specific reference is made to conversation as an accomplishment and pleasurable social activity. There would seem to be no doubt but that this reflects Ó Cianáin's observation of a practice which was being cultivated on the Continent for societal and aesthetic purposes, and regarded as being conducive to family, kindred and community cohesion. Nonetheless, the examples of conversation-inbeing culled from Irish literature more generally and cited in this article bear witness to the ongoing engagement with conversation, discourse and storytelling which has always permeated Irish culture.

\section{University College Dublin}

\section{References}

An Craoibhín Aoibhinn [Hyde, Douglas], 1937, Mo Thurus go hAmerice [My Journey to America], Dublin.

Mac Craith, M., 'Representing Counter-Reformation Rome through Ulster Eyes', in: Ó Fearghail, F., ed., Tadhg Ó Cianáin. An Irish Scholar in Rome, Dublin, 121-70.

Mac Mathúna, L., 2004, 'Scél lem dúib: scéal scéal' ['I Have Tidings for You: The Story of Story'], in: Ó Conaire, B., ed., Aistí ag Iompar Scéil. In Ómós do Shéamus P. Ó Mórdha [Essays Bearing a Story: In Honour of Séamus P. Ó Mórdha], Dublin, 21-36.

Mac Mathúna, L., 2012a, 'Getting to Grips with Innovation and Genre Diversification in the Work of the Ó Neachtain Circle in EighteenthCentury Dublin', Eighteenth-Century Ireland / Iris an Dá Chultúr 27, 53$83)$.

\footnotetext{
9 Author's translation. For a discussion of the significance of this text and the overall corpus of the Ó Neachtains who cultivated Irish scholarship in Dublin in the early eighteenth century see Mac Mathúna (2012a).
} 
Mac Mathúna, L., 2012b, 'Caithréim Thoirdhealbhaigh, a Literary Text: Action, Sensibility and World View', in: Ó Murchú, L. P., ed., Caithréim Thoirdhealbhaigh. Reassessments, London: ITS, 1-32.

Mac Mathúna, L., 2014, 'The Irish Cosmos Revisited', in: Borsje, J., Dooley, A., Mac Mathúna, S., \& Toner, G., eds., Celtic Cosmology. Perspectives from Ireland and Scotland, Toronto, 10-33.

Mac Mathúna, L., 2015, 'Dhá Dhialann Taistil Chaithréimeacha: Tadhg Ó Cianáin ar Mhór-Roinn na hEorpa, 1607-9, agus Dúbhglas de h-Íde i Meiriceá, 1905-6' ['Two Exultant Travel Diaries: Tadhg Ó Cianáin on the European Continent, 1607-9, and Douglas Hyde in America, 1905-6'], in: Nic Congáil, R., Nic Eoin, M., Ní Úrdail, M., Ó Liatháin, P., \& Uí Chollatáin, R., eds., Litriocht na Gaeilge ar fud an Domhain. Cruthú, Caomhnú agus Athbheochan [The Literature of Irish throughout the World: Creation, Preservation and Revival], Vol. I, Dublin, 85-105.

Meid, W., ed., 2015, The Romance of Froech and Findabair or The Driving of Froech's Cattle: Táin Bó Froích, Innsbruck.

Ní Chléirigh, M., ed., 1944. Eólas ar an Domhan i bhFuirm Chomhráidh idir Sheán Ó Neachtain agus a Mhac Tadhg [Knowledge about the World in the Form of a Conversation between Seán Ó Neachtain and his Son Tadhg], Dublin.

O'Grady, S. Hayes, ed., 1929a, Caithréim Thoirdhealbhaigh, Vol. I, London.

O'Grady, S. Hayes, ed., 1929b, Caithréim Thoirdhealbhaigh. The Triumphs of Turlough, Vol. II, London.

Ó Muraíle, N., 2007, From Ráth Maoláin to Rome. Turas na dTaoiseach nUltach as Eirinn [From Ráth Maoláin to Rome: The Journey of the Ulster Chiefs from Ireland], Rome.

Ó Muraíle, N., 2013, 'An Insider's View: Tadhg Ó Cianáin as Eyewitness to the Exile of Ulster's Gaelic Lords 1607-8', in: Gillespie, R., \& Ó hUiginn, R., eds., Irish Europe, 1600-1650. Writing and Learning, Dublin, 44-62.

Walsh, P., ed., 1916, The Flight of the Earls by Tadhg Ó Cianaiin, Maynooth \& Dublin. 